\title{
Pusat Bahasa Mandarin Universitas Al Azhar Indonesia: Refleksi dan Proyeksi Hubungan Sosial Budaya China-Indonesia
}

\author{
Feri Ansori ${ }^{1}$ \\ ${ }^{1}$ Program Studi Sastra China, Fakultas Sastra, Universitas Al Azhar Indonesia, Jl. Sisingamangaraja, \\ Kompleks Masjid Agung Al Azhar, Kebayoran Baru, Jakarta Selatan 12110 \\ Penulis untuk Korespondensi/E-mail: fansori@yahoo.com
}

\begin{abstract}
Abstrak - Kebangkitan China pada awal abad 21 dalam percaturan global dipandang sebagai sebuah fenomena yang menegaskan bahwa dominasi Barat akan segera berakhir dan muncul kekuatan global baru dari kawasan Asia. Hal ini ditanggapi beragam oleh berbagai kalangan, sebagian menganggapnya sebagai suatu hal yang positif, namun sebagian lagi menganggapnya sebagai satu ancaman. Terpilihnya Presiden Joko Widodo pada pemilu 2014 yang mengusung poros maritim dunia dengan tol laut sebagai agenda utama, memunculkan sebuah paradigma baru bagi pemerintah Indonesia dalam memandang Jalur Sutera Maritim Abad 21 (21 ${ }^{\text {st }}$ Maritime Silk Road) yang dicanangkan oleh China sebagai sebuah tantangan atau potensi. Konektifitas dalam Belt and Road Iniative sejalan dengan 5 (lima) pilar utama yang dicanangkan oleh Presiden Joko Widodo dalam program poros maritim dunia. Dalam mensinergikan kebijakan dua pemerintah ini, tentu saja hubungan people-to-people yang terjalin melalui hubungan sosial dan budaya menjadi pilar yang sangat penting. Bagaimana kebijakan pemerintah kedua negara dalam meningkatkan hubungan people-to people, akan sangat berpengaruh dalam keberhasilan kerjasama ini. Makalah ini memaparkan perkembangan hubungan sosial budaya Indonesia-China melalui berbagai kegiatan di Pusat Bahasa Mandarin di Unversitas Al Azhar Indonesia. Pusat Bahasa Mandarin mungkin mampu mengurangi kesan negatif sebagian masyarakat Indonesia terhadap China, tapi terbatas hanya pada beberapa orang saja yang terlibat erat dalam lembaga tersebut.
\end{abstract}

Kata Kunci - Poros maritim dunia, Jalur sutera maritim abad 21, Indonesia, China, People-to-people

Abstract - The rise of China in the early 21st century in the global arena is seen as a phenomenon that resists Western domination will coming to an end and emerging new global powers from the Asian region. This was responded to by various parties, some of them regarded it as a positive thing, but some regard it as a threat. The election of President Joko Widodo in 2014, which brings the maritime axis of the world with the sea toll as the main agenda, has created a new paradigm for the Indonesian government in the view of the 21st Maritime Silk Road by China as a challenge or potential. Connectivity in Belt and Road Iniative is consistent with 5 (five) main pillars proclaimed by President Joko Widodo in the world maritime axis program. In synergizing this, of course the people-to-people relationship that exists through social and cultural relationships becomes a very important pillar. How government policies of both countries in improving people-to people relationship, will be very influential in the success of this cooperation. This paper describes the development of socio-cultural relations between Indonesia and China through various activities at the Mandarin Language Center at Al Azhar University of Indonesia. The Chinese Language Center may be able to reduce the negative impression of Indonesian society on China, but only to a few people who are closely involved in the institution.

Keywords - World maritime axis, 21st century maritime silk trail, Indonesia, China, People-to-people 


\section{PENDAHULUAN}

$\mathrm{K}$ ebangkitan China dalam kancah global ditanggapi beragam oleh berbagai kalangan, sebagian menganggapnya sebagai suatu hal yang wajar, namun sebagian lagi menganggapnya sebagai satu ancaman. Arvind Subramanian ${ }^{1}$ dalam ECLIPSE: Living in the shadow of China's Economic Dominance (Peterson Institute for International Economic, 2011) mengatakan: "China's dominance is not only more imminent, but also broader in scope, and much larger in magnitude, than is currently imagined". ${ }^{2}$

Pada 2013, Presiden China Xi Jinping meluncurkan inisiatif "Jalur Sutera Baru abad ke 21" atau The Silk Road Economic Belt and the $21^{\text {st }}$ century Maritime Silk Road atau yang dikenal juga sebagai Belt and Road Iniative. Tujuannya untuk menciptakan beberapa koridor ekonomi yang membentang di lebih dari 60 negara di seluruh dunia, mengintegrasikan Asia, Eropa dan juga Afrika, baik wilayah darat maupun lautnya. Konektifitas dalam Belt and Road Iniative tercipta dalam 5 hal yakni konsultasi kebijakan, konektifitas infrastruktur, perdagangan bebas, sirkulasi mata uang lokal, dan hubungan people-to-people.

Presiden Joko Widodo yang terpilih pada pemilu 2014 mengusung poros maritim dunia dengan tol laut sebagai agenda utamanya. Hal ini memunculkan paradigma baru bagi pemerintah Indonesia dalam memandang Jalur Sutera Maritim abad $21\left(21^{\text {st }}\right.$ Maritime Silk Road) yang dicanangkan oleh China sebagai sebuah tantangan atau potensi. Lawatan Presiden Joko Widodo dalam forum Kerjasama Tingkat Tinggi Ekonomi Asia Pasifik (APEC) di Beijing China pada 11 November 2014 menunjukan suatu kerjasama serius untuk mensinergikan antara Jalur Sutera Maritim dengan tol laut. Sementara dalam pidatonya pada Konferensi Tingkat Tinggi (KTT) ke-9 East Asia Summit (EAS) tanggal 13 November 2014 di Nay Pyi Taw, Myanmar, Presiden Jokowi menegaskan bahwa Indonesia sebagai

\footnotetext{
${ }^{1}$ Arvind Subramanian is the chief economic adviser for India's Ministry of Finance and author of "Eclipse: Living in the Shadow of China's Economic Dominance."

2 http://www.nytimes.com/roomfordebate/2015/07/27/can-chinastand-on-its-own/chinas-strength-is-obvious-its-future-role-is-not
}

Poros Maritim Dunia akan memfokuskan agenda pembangunan pada 5 (lima) pilar utama, yaitu membangun kembali budaya maritim Indonesia, menjaga sumber daya laut dan menciptakan kedaulatan pangan laut dengan menempatkan nelayan pada pilar utama, memberi prioritas pada pembangunan infrastruktur dan konektivitas maritim dengan membangun tol laut, deep seaport, logistik, industri perkapalan, dan pariwisata maritim.

Adanya kesamaan pandangan mengenai pentingnya konektivitas melalui jalur laut untuk mendukung pembangunan ekonomi inilah yang kemudian membuat kedua negara sepakat untuk mengembangkan kerjasama di sektor maritim. Pemerintah Indonesia dalam lima tahun mendatang (2015-2019) mencanangkan pembangunan jalan tol sepanjang $1000 \mathrm{~km}$, jalan baru $2.650 \mathrm{~km}$, dan pemeliharaan jalan $46.770 \mathrm{~km}$. Selain itu pemerintah juga akan membangun 15 bandara baru, 24 pelabuhan baru, dan juga jalur kereta api sepanjang 3.258 $\mathrm{km}^{3}$. Total dana yang dibutuhkan untuk pembiayaan pembangunan infrastruktur tersebut sebesar USD 381 miliar, dan pemerintah hanya sanggup memenuhi $40 \%$, sisanya diperlukan dana dari pihak swasta dan luar negeri. Melihat kebijakan pemerintah China dalam upaya mengimplementasikan "Jalur Sutera Baru abad ke 21" atau The Silk Road Economic Belt and the $21^{\text {st }}$ century Maritime Silk Road dengan menginisiasi pendirian Asian Infrastructure and Investment Bank dan Silk Road Fund untuk membiayai pembangunan proyek-proyek infrastruktur di negara-negara yang dilalui oleh jalur sutera baru ini, memungkinkan kedua negara untuk menjadi mitra pembangunan.

\section{TINJAUAN PUSTAKA}

\section{Hubungan Indonesia - China}

Hubungan Nusantara dengan China bukanlah hal baru. Sejak zaman Sriwijaya hingga masa Laksamana Cheng Ho keduanya kerap melakukan hubungan baik perdagangan maupun pertukaran budaya serta agama, dan berlanjut terus hingga masa wali songo di Jawa. Ketika Republik Indonesia berdiri pada tahun 1945, tercatat beberapa hubungan bilateral

http://pkps.bappenas.go.id/index.php/berita/143-beritainternal/1257-pemerintah-bangun-1000-km-jalan-tol 
pernah dilakukan keduanya. Indonesia tercatat sebagai negara pertama yang mengakui berdirinya China baru di bawah pemerintahan komunis. Indonesia secara resmi mengakui kedaulatan China pada 15 Januari 1950. Kemudian pada tahun 1953, Indonesia mengutus Arnold Manonutu sebagai Duta Besar Indonesia pertama untuk Beijing, yang diikuti dengan penandatanganan nota kerjasama Indonesia dengan China. Di awal tahun 1960 tercipta poros Jakarta-Peking yang berkembang menjadi poros Jakarta-PekingPyongyang.

Kemudian Indonesia juga pernah memperjuangkan China sebagai anggota tetap Dewan Keamanan PBB yang berujung pada keluarnya Indonesia dari forum itu pada 7 Januari 1965. Hubungan kedua negara juga pernah mencapai titik terendah, yaitu di era Orde Baru, pada Oktober 1967 di bawah pemerintahan Soeharto, Indonesia melakukan pembekuan hubungan bilateral serta hubungan dagang dengan China. Pasca naiknya Deng Xiaoping sebagai pemimpin baru China, maka di tahun 1980-an normalisasi hubungan Jakarta-Beijing mulai disuarakan. Namun keinginan tersebut ditentang oleh berbagai kalangan, terutama Soeharto, Departemen Pertahanan dan Keamanan serta kelompok Islam. Namun pada tahun 1990, di era Soeharto pula upaya normalisasi kembali dilakukan yang ditujukan untuk menggalakkan ekspor nonmigas yang tidak hanya memasuki pasar Jepang dan Barat namun juga China sebagai negara dengan populasi terpadat juga memiliki potensi pasar yang besar bagi produk Indonesia.

Pasca reformasi, seiring proses perubahan arah kebijakan, Indonesia melihat China sebagai sebuah harapan. Naiknya Presiden BJ Habibie merupakan sebuah transisi proses demokratisasi dan kebijakan luar negeri Indonesia, namun masa pemerintahannya sebagian besar masih terfokus perihal peningkatan citra Indonesia di lingkup internasional. Di masa pemerintahan Presiden Abdurrahman Wahid (Gus Dur) merupakan saat dimana China mendapat kedudukan istimewa dalam politik luar negeri Indonesia yang bukan hanya mengarah pada politik dan ekonomi, namun budaya turut menjadi prioritas. Pada masa ini, pertama kali Hari Raya Imlek dijadikan sebagai hari libur nasional. Hubungan itu terus berlanjut pada masa Presiden
Megawati Soekarnoputri, Susilo Bambang Yudhoyono, dan kini Joko Widodo, terutama dalam menyambut era maritim seperti saat ini. Seakan mengulang sejarah, Presiden Joko Widodo mempererat hubungan Indonesia dengan China guna menuju pencapaian yang besar.

\section{HASIL DAN PEMBAHASAN}

\section{Perkembangan Hubungan Sosial-Budaya Indonesia - China}

Dalam beberapa tahun terakhir, hubungan bilateral antara Indonesia dan Tiongkok dalam bidang politik, ekonomi, sosial maupun budaya mengalami perkembangan yang sangat pesat. Hal ini ditandai dengan meningkatnya pertemuan antar pimpinan kedua negara. Sejak Presiden Jokowi menjabat sebagai Presiden RI pada oktober 2014 tercatat telah empat kali bertemu dengan Presiden Xi Jinping yang juga dihadiri oleh para pejabat tinggi kedua negara. Dalam kurun waktu enam tahun terakhir sebanyak 60 kesepakatan kerjasama IndonesiaChina ditandatangani, tidak kurang dari 20 diantaranya merupakan kerjasama dalam kerangka hubungan antar masyarakat (people to people exchange). ${ }^{4}$

Menteri Koordinator Bidang Pembangunan Manusia dan Kebudayaan RI Puan Maharani mengatakan, hubungan antarmasyarakat Indonesia dan China merupakan salah satu sarana pendukung hubungan bilateral kedua negara menjadi lebih kokoh untuk turut memakmuran kawasan ${ }^{5}$.

"Perkuatan hubungan antarmasyarakat RI-RRT membawa semangat baru kedua negara untuk membangun dunia yang berkeadilan dan sejahtera bagi umat manusia."

Misi kebudayaan kedua negara juga telah beberapa kali melakukan pertunjukan di berbagai kota di China dan Indonesia dan mendapat sambutan hangat dari masyarakat setempat. Dalam bidang olahraga beberapa

\footnotetext{
${ }^{4}$ http://www.antaranews.com/berita/576351/menteri-puan-inginhubungan-masyarakat-indonesia-china-ditingkatkan

${ }^{5}$ ibid

${ }^{6}$ Disampaikan dalam pidato pembukaan pada Pertemuan Tingkat Tinggi kedua bidang hubungan antar masyarakat (High Level Meeting People to People Exchange Mechanism) yang diselenggarakan di Guiyang Tiongkok pada 1 Agusutus 2016.
} 
atlet Indonesia telah mendapat pelatihan di China.

Kerjasama pendidikan RI - RRC dilakukan antara lain melalui pemberian beasiswa bagi pelajar Indonesia oleh RRC dan sebaliknya, serta kerjasama penyelenggaraan ujian standarisasi Bahasa Mandarin (HSK) di Indonesia. Jumlah pelajar atau mahasiswa Indonesia yang belajar di China hingga 2015 mencapai 12.694 orang tersebar di berbagai kota di Beijing, Tianjin, Shanghai, Shenzen, Guangzhou, dan Xiamen. Selain itu, pendirian Pusat Bahasa Mandarin (PBM) di Indonesia juga makin mendorong peningkatan jumlah mahasiswa yang belajar ke China. PBM bekerjasama dengan beberapa lembaga pemerintah seperti Departemen Pendidikan, Sekolah Bahasa Polri, Departemen Perdagangan, Kemenhan dll, dan juga memberikan kesempatan kepada para siswa dari lembaga pemerintah tersebut untuk mendapat beasiswa ke China mempelajari bahasa Mandarin dan budaya China. Sedangkan pihak China juga untuk mengirimkan calon pegawai Deplu ke Indonesia untuk pelatihan dan pengenalan bahasa dan budaya Indonesia. Pihak Indonesia melalui program beasiswa Darmasiswa juga telah memberi kesempatan kepada para pelajar China untuk datang ke Indonesia, menempuh pendidikan di beberapa kota di Indonesia seperti Yogyakarta dan Surabaya.

Selain itu, selama kurun waktu 2016 kerjasama dalam bidang pendidikan mengalami beberapa peningkatan kerjasama, diantaranya melalui pendirian Aliansi Think-Tank China Indonesia University pada bulan Juni yang digagas oleh Beijing Foreign Studies University yang beranggotakan dari pihak China yaitu Huazhong Normal University, Guangdong University of Foreign Studies dan Hebei Normal University, serta dari pihak Indonesia beranggotakan Universitas Indonesia, Universitas Gajah Mada, Universitas Negeri Yogyakarta dan Universitas Sumatera Utara, menjadi wadah kerjasama dan pertukaran informasi bagi perguruan tinggi kedua negara. Fujian Normal University dan Huaqiao University pada bulan Nopember juga mendirikan Indonesian Studies Centre, dan di Indonesia berlokasi di Universitas Al Azhar Indonesia juga didirikan Pustaka Kebudayaan China, memberikan kesempatan lebih luas kepada masyarakat kedua negara untuk saling memahami.

Dalam bidang pariwisata, kebijakan pemerintah RI untuk memberikan bebas visa kunjungan kepada warga negara China telah memberikan kontribusi yang sangat besar dalam meningkatkan jumlah kunjungan wisatawan mancanegara ke Indonesia. Pada tahun 2016, wisatawan China menempati peringkat pertama jumlah wisatawan terbanyak yang berkunjung ke tanah air dengan jumlah sebanyak 1.340.760 orang, sedang jumlah wisatawan Indonesia yang berkunjung ke China pada tahun 2015 mencapai 544.800 orang. $^{7}$

\section{Pusat Bahasa Mandarin Universitas Al Azhar Indonesia \\ Confucius Institute (di Indonesia disebut Pusat Bahasa Mandarin), didirikan oleh pemerintah China untuk menyebarkan bahasa dan budaya China dalam rangka mengembangkan hubungan persahabatan antara China dan negara-negara asing, meningkatkan hubungan pendidikan dan pertukaran budaya. Pada tanggal 21 Nopember 2004, Confucius Institute pertama didirikan di Seoul Korea Selatan, sampai dengan akhir tahun 2016 telah berdiri di 140 negara, dengan jumlah total 511 Confucius Institute dan 1073 Confucius Classroom, total jumlah siswa mencapai 2.1 juta orang. ${ }^{8}$}

Pada 28 September 2007, Confucius Institute pertama didirikan atas kerjasama antara lembaga kursus Bahasa Mandarin BTIP (Bina Terampil Insan Persada) dengan Hainan Normal University, dan diberi nama BTIP Confucius Institute. Sayangnya, Confucius Institute belum diakui oleh Departemen Pendidikan Nasional Indonesia, dan pada tahun 2011 ditutup. Tahun 2010 menandai peringatan 60 tahun hubungan diplomatik antara China dan Indonesia, pemerintah Indonesia dan China sepakat mengumumkannya sebagai "ChinaIndonesia Friendship Year." Dalam rangka untuk lebih mempromosikan pertukaran bilateral dankerjasama di bidang pendidikan, pemerintah Indonesia merekomendasikan enam universitas yaitu Universitas Al Azhar Indonesia, Universitas Kristen Maranatha, Universitas Negeri Surabaya, Universitas Negeri Malang, Universitas Hasanudin dan

\footnotetext{
${ }^{7}$ http://kemenpar.go.id/asp/detil.asp?c=110\&id=3139

${ }^{8}$ http://english.hanban.org/node_10971.htm
} 
Universitas Tanjungpura untuk bekerjasama dengan Universitas di China mendirikan Confucius Institute (Pusat Bahasa Mandarin) di Indonesia. Pada tanggal 9 Nopember 2010, Pusat Bahasa Mandarin Universitas Al Azhar resmi berdiri, kemudian berturut-turut diikuti oleh 5 perguruan tinggi lain yang direkomendasikan oleh pemerintah Indonesia (selengkapnya lihat tabel di bawah).

Tabel 1. Enam universitas yang direkomendasikan pemerintah Indonesia untuk bekerja sama dengan Universitas di China mendirikan Conficius Institute

\begin{tabular}{cccc}
\hline $\begin{array}{c}\text { Nama } \\
\text { Institusi }\end{array}$ & $\begin{array}{c}\text { Waktu } \\
\text { Peresmian }\end{array}$ & Kota & $\begin{array}{c}\text { Kampus } \\
\text { China }\end{array}$ \\
\hline PBM & 2010.11 .9 & Jakarta & $\begin{array}{c}\text { Fujian } \\
\text { Normal } \\
\text { Universitas }\end{array}$ \\
Al Azhar & & & University \\
Indonesia & & & Hebei \\
PBM & 2011.2 .9 & Bandung & $\begin{array}{c}\text { Normal } \\
\text { Universitas }\end{array}$ \\
Maranatha & & & University \\
PBM & 2011.2 .22 & Makasar & $\begin{array}{c}\text { Nanchang } \\
\text { University }\end{array}$ \\
Universitas & & & \\
Hasanudin & & & Guangxi \\
PBM & 2011.3 .14 & Malang & Normal \\
Universitas & & & University \\
Malang & & & Central \\
PBM & 2011.5 .19 & Surabaya & China \\
Universitas & & & Normal \\
Negeri & & & University \\
Surabaya & & & Guangxi \\
PBM & 2011.11 .26 & Pontianak & Minzu \\
Universitas & & & University \\
Tanjungpura & & &
\end{tabular}

PBM Universitas Al Azhar Indonesia (UAI) menyelenggarakan kegiatan pengajaran Bahasa Mandarin dan pengenalan budaya China kepada beberapa institusi seperti guru sekolah menengah atas, pegawai pemerintahan, pihak militer dan polisi, staf bandara, siswa sekolah menengah pertama dan siswa sekolah dasar, juga masyarakat umum, memperkenalkan budaya China seperti wushu, kaligrafi, lagu dan tari-tarian China, seni ukir stempel dan lain-lain. Jumlah siswa yang belajar Bahasa Mandarin dan mengikuti kelas budaya China bertambah dari tahun ke tahun. Pada tahun 2016 mengajar sebanyak 78 kelas dengan total jumlah siswa mencapai 2032 orang, memberikan pelatihan pengajaran Bahasa Mandarin kepada 451 orang guru Bahasa Mandarin dari seluruh Indonesia?

\footnotetext{
${ }^{9}$ Data diperoleh melalui wawancara dengan Direktur PBM UAI Pihak China Bapak Huangbin pada tanggal 5 Desember 2016.
}

Sejak berdiri pada nopember 2010, PBM UAI juga telah merekomendasikan ratusan pelajar Indonesia untuk melanjutkan studi ke China baik untuk program gelar maupun non gelar. Selain itu PBM UAI juga telah mengirimkan ratusan orang guru lokal Indonesia untuk mengikuti pelatihan mengajar Bahasa Mandarin di China. Hal ini tentu saja berkontribusi kepada peningkatan hubungan people to people yang pada akhirnya meningkatkan pemahaman masyarakat kedua negara.

Namun di tengah kemajuan pesat yang dicapai oleh PBM UAI, ada beberapa permasalahan yang juga dihadapi, diantaranya adalah mengenai pengurusan visa bagi para guru relawan yang mengajar di PBM UAI, dan juga masa kerja Direktur dan guru relawan yang singkat (hanya 1-2 tahun). Proses pengurusan visa yang begitu lama (3-6 bulan) dengan prosedur yang berbelit-belit telah menghambat kegiatan belajar mengajar di PBM UAI. Selain itu kemampuan Bahasa Indonesia dan pemahaman akan budaya Indonesia dari para guru relawan atau bahkan direktur pihak China pun dirasa masih kurang sehingga terkadang menghambat pekerjaan. Selain itu kurangnya tenaga pengajar Bahasa Mandarin lokal juga menjadi tantangan tersendiri bagi PBM UAI untuk bisa terus meningkatkan jumlah kelas dan mahasiswa.

\section{KESIMPULAN}

Hubungan people-to-people yang terjalin melalui hubungan sosial dan budaya menjadi pilar yang sangat penting dalam hubungan antar negara dalam berbagai bidang. Bagaimana kebijakan masing-masing pemerintah dalam meningkatkan hubungan people-to people, sangat berpengaruh dalam keberhasilan kerjasama tersebut. Pusat Bahasa Mandarin Universitas Al Azhar Indonesia yang merupakan salah satu lembaga yang didirikan untuk memperkenalkan Bahasa dan Budaya China di Indonesia memberikan kontribusi yang besar dalam hubungan people to people sebagai upaya saling pemahaman antar masyarakat kedua negara. Namun berbagai tantangan dan permasalahan yang dihadapi juga memberikan pengaruh kepada keberhasilan hubungan people-to-people di masa yang akan datang. Komunikasi dari instansi terkait kedua 
negara menentukan arah kebijakan dalam penyelenggaraan Pusat Bahasa Mandarin yang pada akhirnya dapat memberikan kontribusi dalam membangun kerjasama yang lebih besar dalam berbagai bidang.

\section{DAFTAR PUSTAKA}

[1] Subramanian, A. 2011. Eclipse: Living in the Shadow of China's Economic Dominance. Washington DC: Peterson Institute for International Economics.
[2] http://www.nytimes.com/roomfordebate/20 15/07/27/can-china-stand-on-itsown/chinas-strength-is-obvious-its-futurerole-is-not

[3] http://pkps.bappenas.go.id/index.php/berit a/143-berita-internal/1257-pemerintahbangun-1000-km-jalan-tol

[4] http://www.antaranews.com/berita/576351 Imenteri-puan-ingin-hubunganmasyarakat-indonesia-china-ditingkatkan

[5] http://kemenpar.go.id/asp/detil.asp?c=110 \&id=3139

[6] http://english.hanban.org/node 10971.htm 